\title{
Implementation of Efficient Artificial Neural Network Data Fusion \\ Classification Technique for Induction Motor Fault Detection
}

\author{
Altaf S. ${ }^{1}$, Mehmood M. S. ${ }^{2}$, Imran M. ${ }^{3}$ \\ ${ }^{1}$ Sensor Network and Smart Environment Research Centre, Auckland University of Technology, Auckland, New Zealand; \\ ${ }^{2}$ Sajid Brothers Engineering Industries, Awais Qarni Road, Gujranwala, Pakistan; \\ ${ }^{3}$ Ministry of Industries and Production, Islamabad, Pakistan
}

\section{Article info:}

Paper received:

The final version of the paper received:

Paper accepted online:
June 7, 2018

September 18,2018

September 22, 2018
*Corresponding Author's Address:

saud.altaf@aut.ac.nz

\begin{abstract}
Reliability measurement and estimation of an industrial system is a difficult and essential problematic task for control engineers. In this context reliability can be described as the probability that machine network will implement its proposed functions under the observing condition throughout a specified time period of running machine system network. In this study single sensor method is applied for fault diagnosis depending on identification of single parameter. At early stages it is hard to diagnose machine fault due to ambiguities in modeling environment. Due to these uncertainties and ambiguities in modeling, decision making become difficult and lead to high financial loss. To overcome these issues between the machine fault symptoms and estimating the severity of the fault; a new method of artificial intelligence fault diagnosis based approach Dempster-Shafer theory has been proposed in this paper. This theory will help in making accurate decision of the machine condition by fusing information from different sensors. The experimental results demonstrate the efficient performance of this theory which can be easily compared between unsurpassed discrete classifiers with the single sensor source data.
\end{abstract}

Keywords: Dempster-Shafer theory, data fusion, fault diagnosis, artificial neural network, fast Fourier transform.

\section{Introduction}

In fault detection of source related to machine condition monitoring, its diagnosis and information gathering are the key steps before it goes into failure. It is also a fact that without availability of prior information machine fault cannot be recognized timely. Condition of fault is mainly dependent on time and available spectrum signature. It is always a difficult task to diagnose the machine fault at preliminary phase due to uncertainties in its modeling. In this context a method of single sensor based on signature of single parameter for diagnosis is suggested in this paper. But sometimes decision goes wrong and may cause loss of throughput and significant financial losses [1].

Yen et al, [2] have advocated the use of data fusion in $\mathrm{CBM}$, since decision making using more than one sensor increases the accuracy of decision. In this scenario, Dempster-Shafer evidence combination or neural nets or fuzzy logic decision making may be used to determine the identity of fault by combining identity declaration from individual sensors.
Fan et. al in [3], studied the features extraction method from raw data, reasoning of faults and decision making derived from diagnostic knowledge. But practically, fault characteristics may be uncertain and inaccurate owing to sensor faults and some restrictions of the feature extraction approaches. Some features may not be visible when any faults are in the initial phase of development. This research introduced an improved membership function, importance of features, evidence capability issues, evidence significance, and conflicting evidences into D-S combination rule in practical application to avoid the important information loss and precision in decision making.

The Dempster-Shafer evidence theory was applied to image segmentation in a Markov field context [4]. The parameter estimation problem was considered as a classical mixture estimation problem. A generalized mixture estimation method was then applied to solve the parameter estimation problem in the context of the multisensory evidential Markov field model. The research shows that the estimated parameter based estimation is close to the true parameter estimation. 
According to the Denoeux [5], D-S evidence theory differentiates between uncertainty and probability functions. These probability functions can be sub class of belief functions and the evidence theory decreases the probability theory when the probability values are wellknown. Denoeux work's further extended by Yang et al in [6]. They modified the method for 3-phase induction motor system, based on current and vibration signal. To increase the performance and precision of fault diagnosis in system, they combined NN algorithm with D-S evidence theory and decision level approach. First of all, features extraction (mean, skewness, kurtosis etc) is managed by one-dimensional (1-D) discrete wavelet transform. Secondly, the extracted data are used for vibration and current inputs of the NN based on D-S theory. Finally, approximated basic belief assignment (BBA) outputs from classifiers are merged by D-S theory for improving the fault diagnosis accuracy.

In this paper, Fault diagnosis based approach Dempster-Shafer theory has been proposed to make an accurate decision of the machine condition by fusing information from different sensors. The experimental results demonstrate the efficient performance of this theory which can be easily compared between unsurpassed discrete classifiers with the single sensor source data.

\section{Research Methodology}

\subsection{Mathematical modeling of Dempster- Shafer (D-S) evidence theory}

\subsubsection{Frame of discernment (Fod)}

The Dempster-Shafer evidence theory employs probability theory to explain the practical uncertainty problems. The Dempster-Shafer evidence method is regarded as a generalized Bayesian theory [1]. The theory can demonstrate support not only for an object but also for the union of objects.

To compute the credibility of distribution from all kinds of faults, let assume $\theta$ be a fixed set of elements and $N$ independent evidence element. We refer the $\theta$ like the FoD [22]; it consists all groups with the subsets of $\theta$ is known as the power of set of $\theta$, and denoted by $2^{\theta}$, when $\theta$ has $n$ elements, $2^{\theta}$ has $2^{n}$ elements.

Suppose $\theta=\left\{F_{1}, F_{2}, \ldots, F_{n}\right\}$, if there is $N$ autonomous reliable distribution function in the identical recognition framework, so $m_{1}, m_{2}, \ldots, m_{n}$, the combine result is [23]:

$$
N=\sum_{\substack{n \\ i=1 \\ i=1}} \prod_{j=\phi}^{n} m_{j}\left(F_{j}\right)
$$

Once the combination, the whole credit assignment function (CAF) is as given below:

$$
m(F)=\left(m_{1} \oplus m_{2} \oplus \ldots \oplus m_{n}\right)(F)=\frac{1}{N} \sum_{\substack{n \\ i=1}} \prod_{j=1}^{n} m_{j}\left(F_{j}\right) .
$$

The reliability distribution function's $m_{i}\left(F_{j}\right)$ of the first $i$ sensor at current state $F_{j}$ and reliability distribution function $R$ is as follows [24]:

$$
m_{i}\left(F_{j}\right)=\frac{C_{i}\left(F_{m}\right)}{\sum_{j=1}^{N_{C}} C_{i}\left(F_{m}\right)+N_{S}\left(1-R_{i}\right)\left(1-\alpha_{i} \beta_{i}\right)},
$$

where $\alpha_{i}, \beta_{i}$ are correlation coefficients.

And reliability distribution function $m_{i}(\theta)$ is in the evidence body $E$ as given below:

$$
m_{i}(\theta)=\frac{N_{S}\left(1-R_{i}\right)\left(1-\alpha_{i} \beta_{i}\right)}{\sum_{j=1}^{N_{C}} C_{i}\left(F_{m}\right)+N_{S}\left(1-R_{i}\right)\left(1-\alpha_{i} \beta_{i}\right)} .
$$

So, the largest correlation coefficients $\alpha_{i}$ as follows:

$$
\alpha_{i}=\max _{j}\left\{C_{i}\left(F_{m}\right)\right\}
$$

And distribution correlation coefficient $\beta_{i}$ is:

$$
\beta_{i}=\frac{1}{N_{C}-1}\left[\frac{N_{C} \alpha_{i}}{\sum_{j=1}^{N_{C}} C_{i}\left(F_{m}\right)}-1\right] .
$$

Sensor reliability coefficient $R_{i}$ could be uncertainty of the CAF:

$$
R_{i}=\alpha_{i} \beta_{i} / \sum_{j=1}^{N_{C}} \alpha_{i} \beta_{i}
$$

Before going to calculate the confidence period, compute the belief proposition function $(\mathrm{Bel})$ and likelihood function $(P l s)$ as follows [23]:

$$
\begin{aligned}
& \operatorname{Bel}(A)=\sum_{B \subseteq A} m(B) ; \\
& P l s(A)=1-\operatorname{Bel}(A)=\sum_{A \cap B} m(B),
\end{aligned}
$$

Where $\operatorname{Bel}(A)$ and $P l s(A)$ are the proposition of $A$ 's the confidence level.

\subsubsection{Dempster's rule of combination}

As discussed above, Dempster's theory has been suggested for the evidence combination when the evidence from dissimilar sources has diminutive difference. Dempster's rule joins many belief functions $(\mathrm{Bel})$ through their respective BPAs. These all belief functions are described on the identical FoD. Although, these are derived from autonomous evidence sources. This theory is based on conjunctive operation. The result of belief function combination consists of conjunctive pooled evidence [4].

Suppose sensor $S_{1}$ observes parametric data and assigns mass probabilities $\left[m p_{1}\left(A_{0}\right), m p_{1}\left(A_{1}\right), m p_{1}\left(A_{2}\right)\right]$ to the 3 propositions and sensor $S_{2}$ assigns the mass probabilities $\left[m p_{2}\left(A_{0}\right), m p_{2}\left(A_{1}\right), m p_{2}\left(A_{2}\right)\right]$ respectively. The following Table 1 summarizes the D-S combination rule for the fault diagnosis. 
Table 1 - D-S combination rule's

\begin{tabular}{|c|c|c|c|}
\hline$S_{2}$ & {$\left[m p_{1}\left(A_{0}\right)\right]$} & {$\left[m p_{1}\left(A_{1}\right)\right]$} & {$\left[m p_{1}\left(A_{2}\right)\right]$} \\
\hline$\left[m p_{2}\left(A_{0}\right)\right]$ & $m p\left(A_{0}\right)=m p_{1}\left(A_{0}\right) m p_{2}\left(A_{0}\right)$ & $k_{07}=m p_{1}\left(A_{0}\right) m p_{2}\left(A_{0}\right)$ & $m p\left(A_{0}\right)=m p_{1}\left(A_{0}\right) m p_{2}\left(A_{0}\right)$ \\
\hline$\left[m p_{2}\left(A_{1}\right)\right]$ & $k_{06}=m p_{1}\left(A_{0}\right) m p_{2}\left(A_{0}\right)$ & $m p\left(A_{0}\right)=m p_{1}\left(A_{0}\right) m p_{2}\left(A_{0}\right)$ & $m p\left(A_{0}\right)=m p_{1}\left(A_{0}\right) m p_{2}\left(A_{0}\right)$ \\
\hline$\left[m p_{2}\left(A_{2}\right)\right]$ & $m p\left(A_{0}\right)=m p_{1}\left(A_{0}\right) m p_{2}\left(A_{0}\right)$ & $k_{10}=m p_{1}\left(A_{0}\right) m p_{2}\left(A_{0}\right)$ & $m p\left(A_{0}\right)=m p_{1}\left(A_{0}\right) m p_{2}\left(A_{0}\right)$ \\
\hline
\end{tabular}

The matrix elements shown in Table 1, are the joint the evidences of two sensors which assigned as per the combination rule. The joint probability for equal propositions, products of the masses are given by each of sensor.

Dempster's rule of combination [24] calculates a normalization factor nf which is the total of the masses given by the divergence propositions (Figure 1).

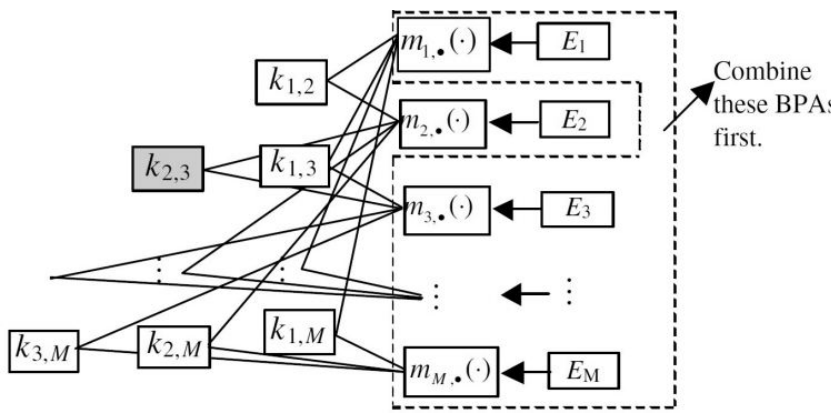

Figure 1 - Classification of evidences [1]

The Dempster's combination rule subsequently may be inscribed for two autonomous sources as:

$$
\begin{aligned}
& m p\left(A_{l}\right)=\frac{\sum_{A_{i} \mid B_{j}=C} m p_{1}\left(A_{i}\right) m p_{2}\left(B_{j}\right)}{1-n f} ; \\
& n f=\sum_{A_{i} \mid B_{j}=\phi} m p_{1}\left(A_{i}\right) m p_{2}\left(B_{j}\right),
\end{aligned}
$$

where $\varnothing$ represent the empty set and $A_{i}$ defined as a general proposition.

\section{Results}

We suppose the three evidences to perform the online monitoring of induction motors in MATLAB and Dempster-Shafer Engine 1.0 (DSE) is used for the fusing sensors data. For that, an enormous number of different signals exist in production line to detect the three hypotheses were chosen as faults types. Three evidences sources against these fault types in healthy and faulty motors and mass probabilities functions are shown in the following Table 2.
Table 2 - Sources of mass probabilities functions in Healthy machine

\begin{tabular}{|c|c|c|c|c|}
\hline \multirow{2}{*}{$\begin{array}{c}\text { Evidences } \\
\text { sources }\end{array}$} & \multicolumn{3}{|c|}{ Sensor number } & Diagnosis \\
\cline { 2 - 4 } & 1 & 2 & 3 & result \\
\hline Evidence 1 & 0.011 & 0.003 & 0.011 & uncertainly \\
\hline Evidence 2 & 0.001 & 0.000 & 0.000 & healthy \\
\hline Evidence 3 & 0.000 & 0.000 & 0.000 & healthy \\
\hline
\end{tabular}

In each case the condition signal provides a qualitative indication of the sensor fault. The only significant temporal resolution of the method used to estimate the frequency spectrum. Temporal resolution can be improved by increasing the overlap of blocks but this incurs a significant computational penalty.

Figure 2 a shows the effect of a sensor hard over fault and failure which is initially detected using samples in the block 94-150 minutes, however the sensor status value is only reduced to 0.59 as the first 19 samples in the block are obtained from a healthy sensor. The status value is reduced to zero by data in the block 119-175 minutes and all subsequent blocks. In Figure 2 b, the sensor is unpredictable from 95 minutes. The sensor status output is reduced appropriately by data in the block 85-145 minutes and all subsequent blocks. Figure $2 \mathrm{c}$ demonstrates that a sensor point fault at 83 minutes and the sensor status value is reduced to 0.09 by data in the block 47-139 minutes but returned to unity by data in the block 77-133 minutes. In response to the sensor fixed fault at 110 minutes the sensor status value is reduced suitably by data in the block 110-210 minutes and all subsequent blocks.

The following Tables 3, 4 shows the specification of features classification and accuracy of each fault class for network training and data testing with 100 evidence trees, with splitting one class variable for each split with their accuracy percentage against each evidence. For features classification, specific numbers of sample are taken by each sensor, and train it through proposed theory.

The following Figure 3 presents the performance errors against each targeted class. As we can observed that in classification of class 1 and 3; the required best epoch is near 32 and 26, which is not close targeted value which shows the less accuracy in training. Instead, class 2 is very adjacent and shows the healthy state of evidence class. 

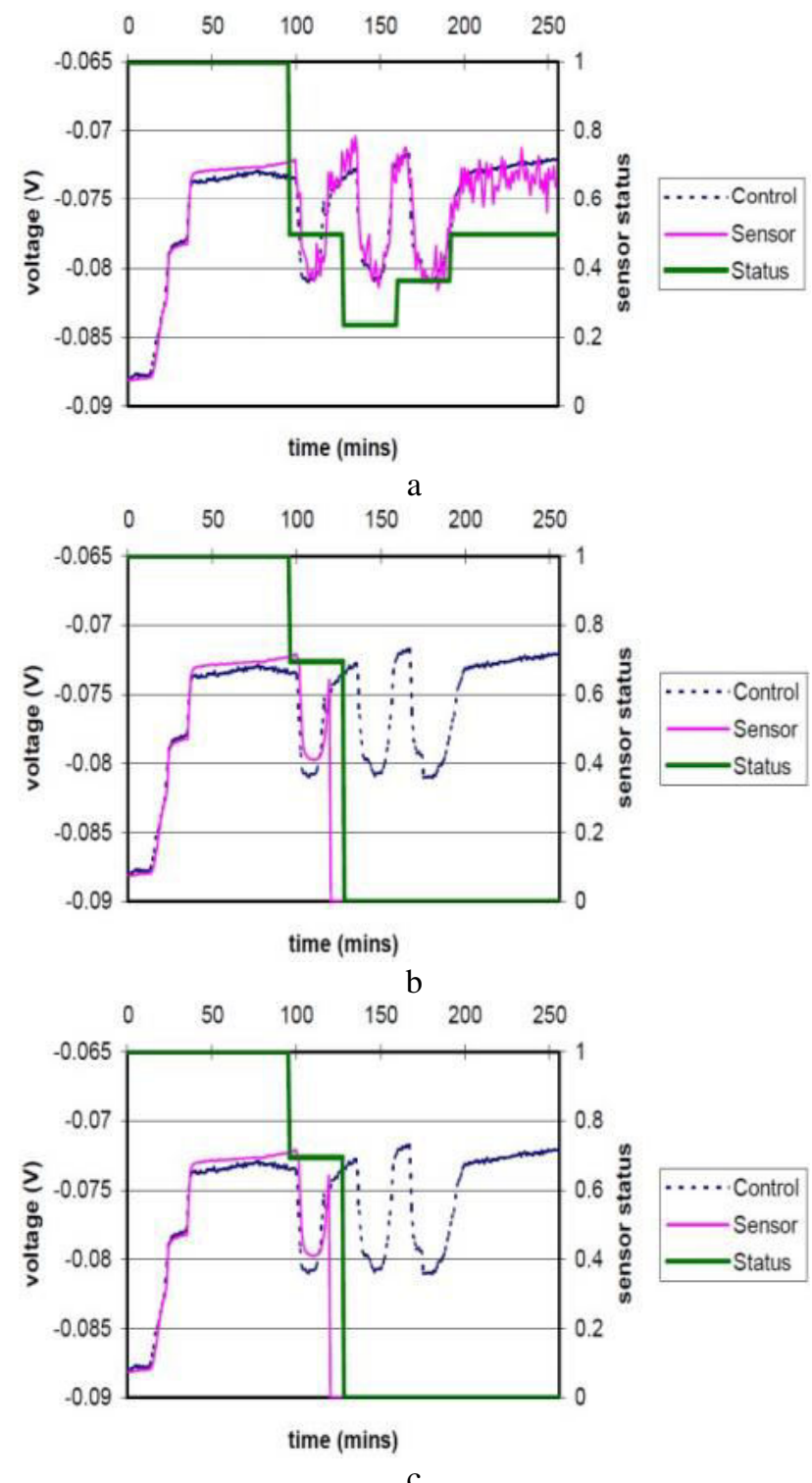

Figure 2 - Confidence in different hypothesis at sensor 1 (a), 2 (b), and 3 (c)

Table 3 - Specification of features classification

\begin{tabular}{|c|c|c|c|c|}
\hline Class & Condition & Samples & $\begin{array}{c}\text { Training } \\
\text { sample }\end{array}$ & $\begin{array}{c}\text { Testing } \\
\text { sample }\end{array}$ \\
\hline 1 & uncertainly & 10 & 15 & 15 \\
\hline 2 & healthy & 10 & 15 & 15 \\
\hline 3 & uncertainly & 10 & 15 & 15 \\
\hline
\end{tabular}

Table 4 - Each fault class accuracy with trees structure

\begin{tabular}{|c|c|c|c|c|c|c|c|c|c|c|}
\hline \multirow{2}{*}{ Class } & \multicolumn{10}{|c|}{ Confusion matrix } \\
\cline { 2 - 12 } & 1 & 2 & 3 & 4 & 5 & 6 & 7 & 8 & 9 & 10 \\
\hline 1 & 10 & 0 & 0 & 0 & 0 & 0 & 5 & 0 & 0 & 0 \\
\hline 2 & 0 & 10 & 0 & 0 & 0 & 4 & 0 & 0 & 0 & 0 \\
\hline 3 & 0 & 0 & 10 & 0 & 0 & 0 & 0 & 0 & 10 & 0 \\
\hline
\end{tabular}
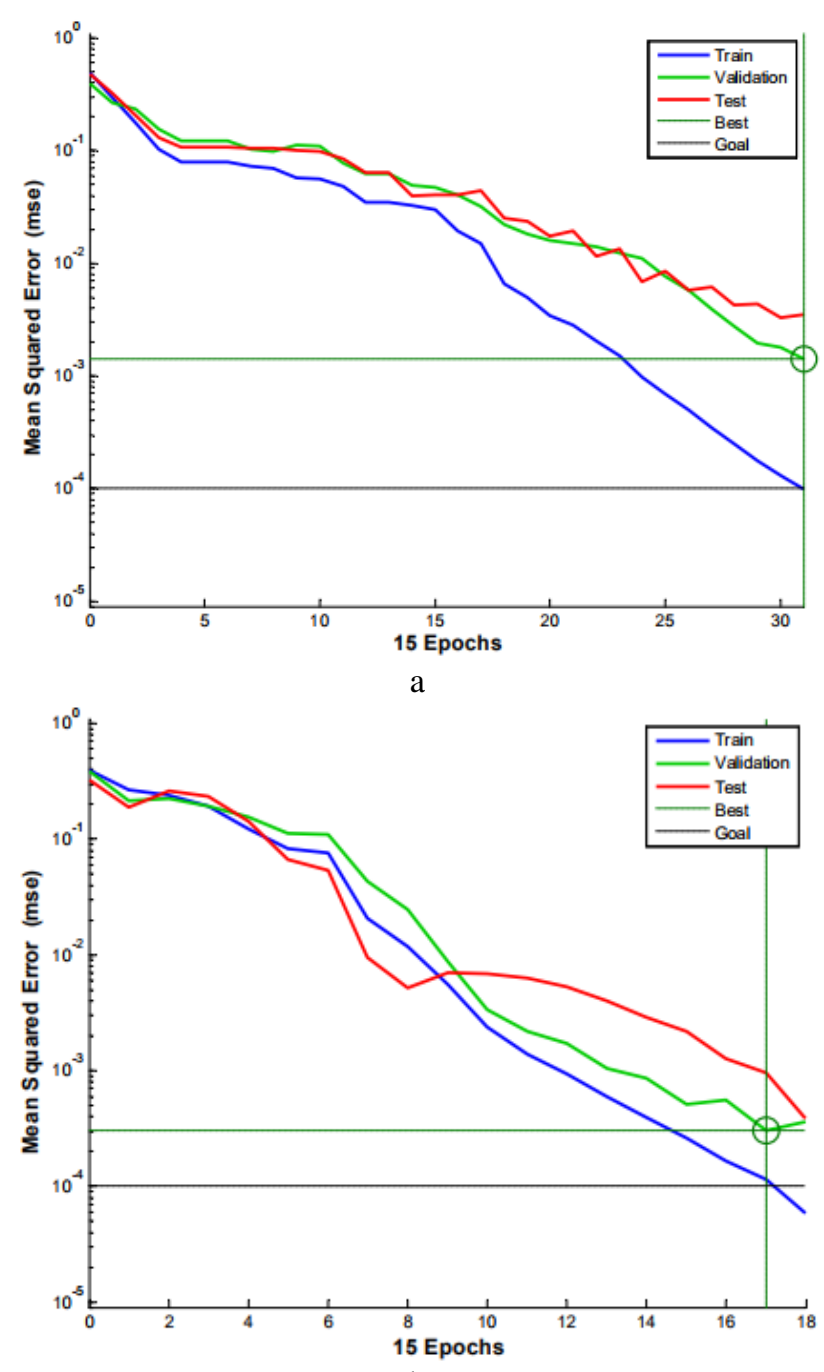

b

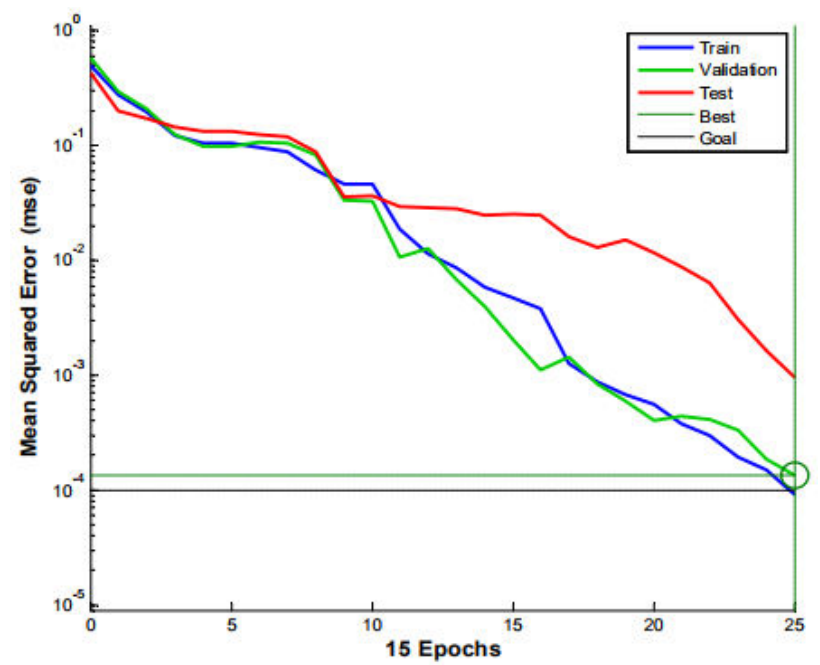

c

Figure 3 - Class 1 (a), 2 (b), and 3 (c) performance 
Figure 4 shows the error percentage of all the evidences.

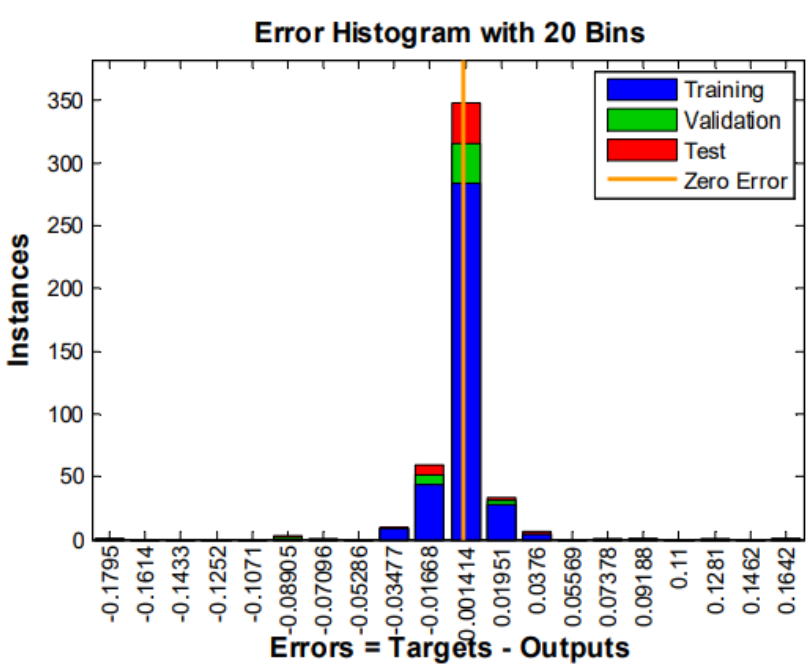

Figure 4 - Overall error percentage instances

\section{Conclusions}

This paper discussed the machine fault diagnosis using the sensor fusion technique D-S evidence theory. Through the theoretical and practically, we found this theory very efficient and realistic in machine fault diagnosis concept. A critical comparison is also performed between the different sensors fusion in respect to time which also show the accuracy percentage of D-S. The results shows that it effectively enhance the reliability of machine diagnosis and very much decreased the probability of uncertainty. It also detects the different faults timely to reduce the cause loss of throughput and significant financial losses among the industries. Therefore, it can be believed that the fault diagnosis of electric machines is a significant investigate topic with great potential for application in industry.

\section{Acknowledgements}

The authors would like to thanks to Sajid Brothers Engineering Industries (Pvt.) Ltd Gujranwala Pakistan for technical support.

\section{References}

1. Fan, X. F., \& Zuo, M. J. (2006). Fault diagnosis of machines based on D-S evidence theory. Part 2: Application of the improved D-S evidence theory in gearbox fault diagnosis. Pattern Recognition Letters, Vol. 27, pp. 377-385.

2. Fan, X., \& Hu, Y. (2007). Target Identif ication Based on Neural Network and D-S Evidence Theory. Transactions of Shenyang Ligong University, Vol. 26, No. 5, pp. 33-36.

3. Yen, J. (2003). Discussion of Dempster's-Shafer's Theory. D. Hall, State College, PA.

4. Gestel, T. V., \& Suykens, J. A, Lanckriet, K., Lambrechts, G., De Moor, B., \& Vandewalle, J. (2002). Bayesian Framework for Least Squares Support Vector Machine Classifiers, Gaussian Processes and Kernel Fisher Discriminant Analysis. Neural Computation, Vol. 15, No. 5, pp. 1115-1142.

5. Denoeux, T. (1999). Reasoning with imprecise belief structures. International Journal of Approximate Reasoning, pp. 79-111.

6. Luo, H., Yang, S.-L., Hu, X.-J., \& Hu, X.-X. (2012). Agent oriented intelligent fault diagnosis system using evidence theory. Expert Systems with Applications, Vol. 39, Issue 3, pp. 2524-2531.

7. Smets, P. (1990). The combination of evidence in the transferable belief model. IEEE Transactions on Pattern Analysis and Machine Intelligence, Vol. 12, No. 5, pp. 447-458.

8. Basir, O., \& Yuan, X. (2007). Engine fault diagnosis based on multi-sensor information fusion using Dempster-Shafer evidence theory. Information Fusion.

9. Yager, R. R. (1987). On the Dempster-Shafer framework and new combination rules. Information Sciences, Vol. 41, No. 2, pp. 93-137.

10. Zadeh, L. A. (1986). Simple view of the dempster-shafer theory of evidence and its implication for the rule of combination. Artificial Intelligence, Vol. 7, No. 2, pp. 85-90.

11. Murphy, R. R. (1998). Dempster-Shafer theory for sensor fusion in autonomous mobile robots. IEEE Transactions on Robotics and Automation, Vol. 14, No. 2, pp. 197-206.

12. Dubois, D., \& Prade, H. (1988). Representation and combination of uncertainty with belief functions and possibility measures. Computational Intelligence, Vol. 4, No. 3, pp. 244-264.

13. Murphy, C. K. (2000). Combining belief functions when evidence conflicts. Decision Support Systems, Vol. 29, No. 1, pp. 1-9.

14. Zhang, J., Fan, X., Huang, C., \& Chen, T. (2008). Fusion monitoring system of locomotive wheel set state. Journal of Traffic and Transportation Engineering, Vol. 8, No. 6, pp. 13-19.

15. Asakura, T., Kobayashi, T., \& Hayashi, S. (1999). A study of Fault Diagnosis System Using Neural Networks. Proceedings of IMEKO-XV World Congress TC-10, pp. 39-44.

16. Adgar, A., Cox, C., \& MacIntyre, J. (1998). Automatic fault diagnosis for rotating machinery using statistical and neural network techniques. 11th International Congress and Exhibition on Condition Monitoring and Diagnostic Engineering Management "COMADEM 98".

17. Zolghadri, A. (1996). An Algorithm for Real-Time Failure Detection in Kalman Filters. IEEE Transactions on Automatic Control, Vol. 41, No. 10, pp. 1537-1539. 
18. Buczak, A. L., \& Uhrig, R. E. (1993). Hybrid neural network - fuzzy logic diagnosis system for vibration monitoring. Proceedings of Artificial Neural Networks in Engineering Conference "ANNIE-93”, pp. 757-762.

19. Siu, C. C., Shen, Q, \& Milne, R. A. (1997). Fuzzy Expert System for Turbomachinery Diagnosis. IEEE Int. Conference on Fuzzy Systems, Vol. 1, pp. 555-560.

20. Hu, Z., Cai, Y., He, X., \& Xu, X. (2005). Fusion of multi-class support vector machines for fault diagnosis. American Control Conference, Vol. 3, pp. 1941-1945.

21. Bendjebbour, A., \& Pieczynski, W. (1998). Unsupervised image segmentation using Dempster-Shafer fusion in a Markov fields context. Proceedings of the 1st International Conference on Multisource-Multisensor Information Fusion.

22. Hall, D. L., \& McMullen, S. A. H. (2004). Mathematical Techniques in Multisensor Data Fusion. Artech House Publishers.

23. Shengqiang, W., Wanlu, J. (2009). Research on Data Fusion Fault Diagnosis Method Based on DS Evidence Theory. International Conference on Measuring Technology and Mechatronics Automation “ICMTMA '09”, Vol. 1, pp. 689-692.

24. Shao, W. Y. H., \& Wang, X. (2004). Soft sensing modeling based on support vector machine and Bayesian model selection. Computers and Chemical Engineering, Vol. 28, Issue 8, pp. 1489-1498.

\title{
Впровадження ефективної методики класифікації злиття даних для визначення несправностей асинхронного двигуна із застосуванням штучної нейронної мережі Альтаф C. ${ }^{1}$, Мехмуд М. С. ${ }^{2}$, Імран M. ${ }^{3}$ \\ ${ }^{1}$ Дослідницький центр мережі датчиків та інтелектуального середовища, Оклендський технологічний університет, м. Окленд, Нова Зеландія; ${ }^{2}$ Інженерна компанія “Sajid Brothers”, шлях Авайз Карні, м. Гуджарвала, Пакистан; \\ ${ }^{3}$ Міністерство промисловості та виробництва, м. Ісламабад, Пакистан
}

\begin{abstract}
Анотація. Визначення надійності та оцінка промислової системи є важким і важливим проблемним завданням для інженерії керування. У цьому контексті надійність може бути охарактеризована як вірогідність того, що машинна мережа реалізує свої запропоновані функції в умовах спостереження впродовж певного часового проміжку, коли працює система машинної мережі. У цьому дослідженні застосовується метод одиночного датчика для діагностування несправностей залежно від ідентифікації одного параметра. На ранніх етапах важко діагностувати помилку машини через невизначеність у середовищі моделювання. 3 огляду на ці факти, невизначеності і двозначності в моделюванні, прийняття рішень стає складним завданням і призводить до значних фінансових втрат. Для подолання цих проблем між проявами несправності машини та оцінкою іiі ступеня в роботі запропоновано новий підхід із застосуванням штучного інтелекту на основі теорії

Демпстера-Шафера. Ця теорія дозволяє більш точно визначати стан машини шляхом об'єднання інформації 3 різних датчиків. Результати числового експерименту демонструють високу ефективність запропонованої методики у порівнянні з дискретними класифікаторами з вихідними даними одиночних датчиків.
\end{abstract}

Ключові слова: теорія Демпстера-Шафера, злиття даних, діагностування несправностей, штучна нейронна мережа, швидке перетворення Фур'є. 